\title{
EFFECTS OF EXOGENOUS CADMIUM ON ACTIVITY OF ANTIOXIDANT ENZYME, CD UPTAKE AND CHEMICAL FORMS OF RYEGRASS
}

\author{
QIN, Y. ${ }^{\#}-\mathrm{LI}, \mathrm{X}^{\#}$ - XU, W. ${ }^{*}$ - CHAI, Y. - CHI, A. - WANG, W. - LI, T. - HUANG, C. - ZHENG, Y. \\ College of Resources and Environmental Sciences, Southwest University \\ Chongqing 400715, P. R. China \\ (phone: +08-6-10-236-825-1249) \\ ${ }^{\#}$ These authors should be considered co-first authors. \\ *Corresponding author \\ e-mail:xuwei_hong@163.com \\ (Received 24 $4^{\text {th }}$ Jun 2017; accepted $25^{\text {th }}$ Sep 2017)
}

\begin{abstract}
The cadmium (Cd) contamination in farmland soils in China has been becoming more and more serious because of the large amount of industrial waste residue, sewage irrigation and the unreasonable application of pesticides and fertilizers. Pot experiment was conducted to study the effects of different $\mathrm{Cd}$ levels $\left(0,75,150,300\right.$ and $\left.600 \mathrm{mg} \cdot \mathrm{kg}^{-1}\right)$ on dry weight, activities of antioxidant enzyme and $\mathrm{Cd}$ chemical forms of the two ryegrass varieties (Band and Arbde). The results showed that dry weights of shoot and plant of ryegrass (Band and Arbde) were firstly increased with the increase of Cd level, which reached the highest values respectively at $75 \mathrm{mg} \cdot \mathrm{kg}^{-1}$ and $150 \mathrm{mg} \cdot \mathrm{kg}^{-1}$, and respectively increased by $10.06 \%$ and $4.04 \%, 25.84 \%$ and $16.89 \%$ compared with the control. Shoot $\mathrm{Cd}$ concentrations of Band and Arbde were $171.827 \mathrm{mg} \cdot \mathrm{kg}^{-1}$ and $169.122 \mathrm{mg} \cdot \mathrm{kg}^{-1}$ respectively at $150 \mathrm{mg} \cdot \mathrm{kg}^{-}$ ${ }^{1} \mathrm{Cd}$. The average $\mathrm{Cd}$ concentrations of chemical forms in shoots of the two ryegrass varieties were in order of $\mathrm{NaCl}$ extractable $\mathrm{Cd}\left(F_{\mathrm{NaCl}}\right)>$ acetic acid extractable $\mathrm{Cd}\left(F_{\mathrm{HAC}}\right)>$ water extractable $\mathrm{Cd}$ $\left(F_{\mathrm{W}}\right)>$ residual $\mathrm{Cd}\left(F_{\mathrm{R}}\right)>\mathrm{HCl}$ extractable $\mathrm{Cd}\left(F_{\mathrm{HCl}}\right)>$ alcohol extractable $\mathrm{Cd}\left(F_{\mathrm{E}}\right)$. Compared with the two ryegrass varieties, Arbde was more effective in remediation of cadmium contamination in soils due to higher plant biomass and greater $\mathrm{Cd}$ accumulation.
\end{abstract}

Keywords: $C d$ contamination; ryegrass; activity of antioxidant enzyme; $C d$ uptake; $C d$ chemical forms

\section{Introduction}

Cadmium (Cd) pollution in soil has become a global issue due to the emission of three types of industrial waste, i.e. mining, chemical fertilizers and pesticides used in agriculture and sewage irrigation (Ren et al., 2014; Hejazi et al., 2017). The Yangtze River Basin is located in cadmium ore resources enrichment area of China, and there were reports that $\mathrm{Cd}$ content in soils and agricultural products exceeds Chinese government standard (Sun et al., 2016). The soil Cd pollution around smelting plant is more serious, for example, in the investigation of the surrounding environment of a smelting plant in Northeast China, it is found that the content of $\mathrm{Cd}$ in collected soil samples is from 4.1 to $167.6 \mathrm{mg} \cdot \mathrm{kg}^{-1}$ (Chen, 2016; Hashemi, 2017). Cadmium is highly toxic to plants, water soluble and therefore promptly adsorbed in tissues and its presence greatly influences the entire plant metabolism (Li et al., 2016). Cadmium pollution has the characteristics of concealment, latency, accumulation and long term, which could access to biological body with long-term accumulation through the food chain, thus endangering human health, such as Japan's "Itai-Itai Disease" (Liu et al., 2015). 
Phytoremediation as a kind of in-situ remediation technology with low cost and small environmental disturbance, is considered to be the best remediation method of heavy metal contaminated soil (Chen et al., 2015; Radan et al., 2017). At present, Cd enrich plants has been found included Solanum nigrum L., Zygophyllum fabago L., Arabidopsis thaliana. L., Trifolium repens L. and Iris hex agona L., etc (Chen, 2016). Unfortunately, most of the plants that were already found out to have lots of accumulation of Cd grow slowly, and have low biomass so that their restoration takes a long period, while they require grow in very restricted conditions. These conditions limit using phytoextraction technology at large scale. Ryegrass (Lolium multiflorum L.) is the annual or perennial herbs, and is a kind of forage grass with higher yield in gramineous plants. It has been reported that ryegrass is an ideal plant for phytoremediation of heavy metals in soils due to surviving in tailings with poor ecological environment, and fast vegetation construction and strong tiller ability, and rapidly covering the ground (Xu et al., 2007; Wu et al., 2014; Xiang, 2014). Perennial ryegrass have obvious remediation effect on Cd polluted soil (Feng et al., 2016; Sun et al., 2016; Vazdani et al., 2017). Studies on the growth and Cd uptake by ryegrass under Cd stress have been reported (Xu et al., 2007; Chen et al., 2015; Feng et al., 2016), however, there are few studies on difference of $\mathrm{Cd}$ resistance, $\mathrm{Cd}$ uptake and $\mathrm{Cd}$ chemical forms between ryegrass varieties. In order to further explore the effects of different Cd levels $\left(0,75,150,300\right.$ and $\left.600 \mathrm{mg} \cdot \mathrm{kg}^{-1}\right)$ on growth, activity of antioxidant enzyme and the $\mathrm{Cd}$ chemical forms in ryegrass, two ryegrass varieties (Band and Arbde) planted in pots containing $\mathrm{Cd}$ pollution and were then analyzed (Ahamed and Lognathan, 2017). This work will provide interesting data for studying on the expression difference of $\mathrm{Cd}$ accumulation /Cd tolerance related genes between ryegrass varieties, and breeding and cloning high biomass and high $\mathrm{Cd}$-enrichment varieties in future research.

\section{Materials and methods}

\section{Plant material, soil and Cd treatments}

Two ryegrass (Lolium multiflorum L.) varieties (Band and Arbde) were used in the present study. The seeds were purchased from Jiangxi Scarecrow agricultural park. Purple soil based on Chinese Soil Taxnomy (CST) was collected from purple soil base of Southwestern University in Beibei region, Chongqing. The contents of organic matter, total nitrogen, alkali-degradable nitrogen, available $\mathrm{P}$, available $\mathrm{K}, \mathrm{Cd}$ in soil, and the soil $\mathrm{pH}$ were $8.87 \mathrm{~g} \cdot \mathrm{kg}^{-1}, 1.54 \mathrm{~g} \cdot \mathrm{kg}^{-1}, 74.60 \mathrm{mg} \cdot \mathrm{kg}^{-1}, 65.07 \mathrm{mg} \cdot \mathrm{kg}^{-1}, 38.59 \mathrm{mg} \cdot \mathrm{kg}^{-1}$, $0.110 \mathrm{mg} \cdot \mathrm{kg}^{-1}$, and 5.23 , respectively.

The pot experiment was conducted with $\mathrm{Cd}$ concentrations of $0,75,150,300$ and $600 \mathrm{mg} \cdot \mathrm{kg}^{-1}\left(\mathrm{CdCl}_{2} \cdot 2.5 \mathrm{H}_{2} \mathrm{O}\right)$ from March 3, 2015 to May 5, 2015 in the greenhouse of College of Resources and Environmental Sciences at Southwest University, China. $5 \mathrm{~kg}$ of air-dried soil was passed through a 40-mesh screen and then treated with $\mathrm{CdCl}_{2} \cdot 2.5 \mathrm{H}_{2} \mathrm{O}\left(0,75,150,300\right.$ and $\left.600 \mathrm{mg} \cdot \mathrm{kg}^{-1}\right)$ solution and mixed to be homogeneously put in a plastic pot (diameter, $25 \mathrm{~cm}$; height, $17 \mathrm{~cm}$ ) and kept balance for two weeks. Thirty seedlings with the same growth potential were planted in each pot. The base fertilizer included $\mathrm{P}\left(\mathrm{NH}_{4} \mathrm{H}_{2} \mathrm{PO}_{4}\right), \mathrm{K}(\mathrm{KCl})$, and $\mathrm{N}\left(\mathrm{NH}_{4} \mathrm{H}_{2} \mathrm{PO}_{4}\right.$ and urea) at concentrations of $100 \mathrm{mg} \cdot \mathrm{kg}^{-1}, 150 \mathrm{mg} \cdot \mathrm{kg}^{-1}$, and $180 \mathrm{mg} \cdot \mathrm{kg}^{-1}$, respectively. The seedlings of ryegrasses (Lolium multiflorum L.) with $10 \mathrm{~cm}$ high were then transplanted 30 plant for each pot. The moisture content in soil was kept $60 \%$ of the maximum 
moisture in the fields with deionized water. Fast- measurement of Soil Moisture (TZSIW, Zhejiang Tuopu Instrument Co., Ltd., China) was used to determine the moisture content in soil. The experiment was performed in triplicate, and was randomized complete block arrangement. The plants were harvested on May 5, 2015, and were kept at 105 DEG C for 15 min for denaturing the enzymes, and then oven-dried at 60 DEG C until there was no further change in the weight of the sample.

\section{Soil physical and chemical properties}

Soil $\mathrm{pH}$ was determined by soil water ratio of 1:2.5; organic matter, total nitrogen, available nitrogen, available phosphorus and available potassium in soils were determined by conventional analysis methods (Yang et al., 2008; Issaka and Ashraf, 2017; Xiao et al., 2017).

\section{Antioxidant enzyme activity and MDA content}

Tissue samples of shoot and root in two ryegrass (Lolium multiflorum L.) varieties (Band and Arbde) were homogenized in ice-cold deoxygenated $20 \mathrm{mmol} \cdot \mathrm{L}^{-1}$ Tris-HCl buffer $(\mathrm{pH} 7.4,1: 9, \mathrm{~W} / \mathrm{V})$ and centrifuged at $3000 \times \mathrm{g}$ for $10 \mathrm{~min}$. Aliquots of $100 \mu \mathrm{L}$ were used for enzyme activity measurement. The activity of catalase (CAT) was measured using a microtiter plate assay (Grant et al., 2008; Yang et al., 2017). The activity of peroxidase (POD) was determined by monitoring the increase in absorbance at $470 \mathrm{~nm}$ during the oxidation of guaiacol (Hemeda and Klein, 1990). The activity of superoxide dismutase (SOD) was determined by the method of Minami and Yoshikawa (1979) with $50 \mathrm{mmol} \cdot \mathrm{L}^{-1}$ Tris-Ca-codylic sodium salt buffer $(\mathrm{pH} \mathrm{8.2)}$ containing 0.1 mmol $\cdot \mathrm{L}^{-1}$ EDTA.

\section{Plant Cd fraction}

The concentrations of $\mathrm{Cd}$ in its various chemical forms in ryegrass shoots were determined through continuous leaching method (Tessier et al., 1979). A flame atomic absorption spectrometer (Perkin SIMMA 6000 Elmer, Norwalk, USA) was used to determine Cd concentration. The detection limit was $0.005 \mathrm{mg} \cdot \mathrm{kg}^{-1}$. The plant reference material (GBW \# 08513) provided by National Institute of Standards and Technology was adopted to monitor the quality of determination results. The recovery rates of cadmium in all plant samples were higher than 95\%, and the accuracy of relative standard deviation (RSD) was less than $10 \%$.

\section{Soil Cd fraction}

The concentrations of $\mathrm{Cd}$ in its various chemical forms in soil was conducted by five-step sequential extraction method proposed by Tessier et al. (1979), and the extracted $\mathrm{Cd}$ was determined by atomic absorption spectrophotometry (Perkin Elmer SIMMA 6000, Norwalk, USA). The detection limit was $0.005 \mathrm{mg} \cdot \mathrm{kg}^{-1}$. The plant reference material (GBW \# 08303) provided by National Institute of Standards and Technology was adopted to monitor the quality of determination results. The recovery rates of $\mathrm{Cd}$ in all plant samples were higher than $95 \%$, and the accuracy of relative standard deviation (RSD) was less than 10\% (Zhao and Chen, 2017). 


\section{Statistical analysis}

Three-way analysis of univariate ANOVA and correlation analysis were performed using SPSS version 21.0 package (SPSS, 2012). The effects of interaction among Cd levels on dry weight of plant, antioxidant enzyme activity, $\mathrm{Cd}$ concentration and $\mathrm{Cd}$ uptake in plant, and $\mathrm{Cd}$ fraction in plant and soil for different ryegrass varieties was subjected to a two-way analysis of variance (ANOVA; i.e., varieties and Cd treatments) followed by the least significant difference (LSD) test $(p<0.05)$ (Xu et al., 2010).

\section{Results}

\section{Biomass}

As shown in Figure 1, with the increase of Cd level in soils, shoot dry weight of Band and Arbde were increased. Highest shoot dry weight of Band was found in 75 $\mathrm{mg} \cdot \mathrm{kg}^{-1} \mathrm{Cd}$ and increased by $10.06 \%$ compared with the control, while highest shoot dry weight of Arbde was observed at $150 \mathrm{mg} \cdot \mathrm{kg}^{-1} \mathrm{Cd}$ and increased by $25.84 \%$ compared with the control. At the same Cd level, shoot dry weight of Arbde was higher than that of Band.
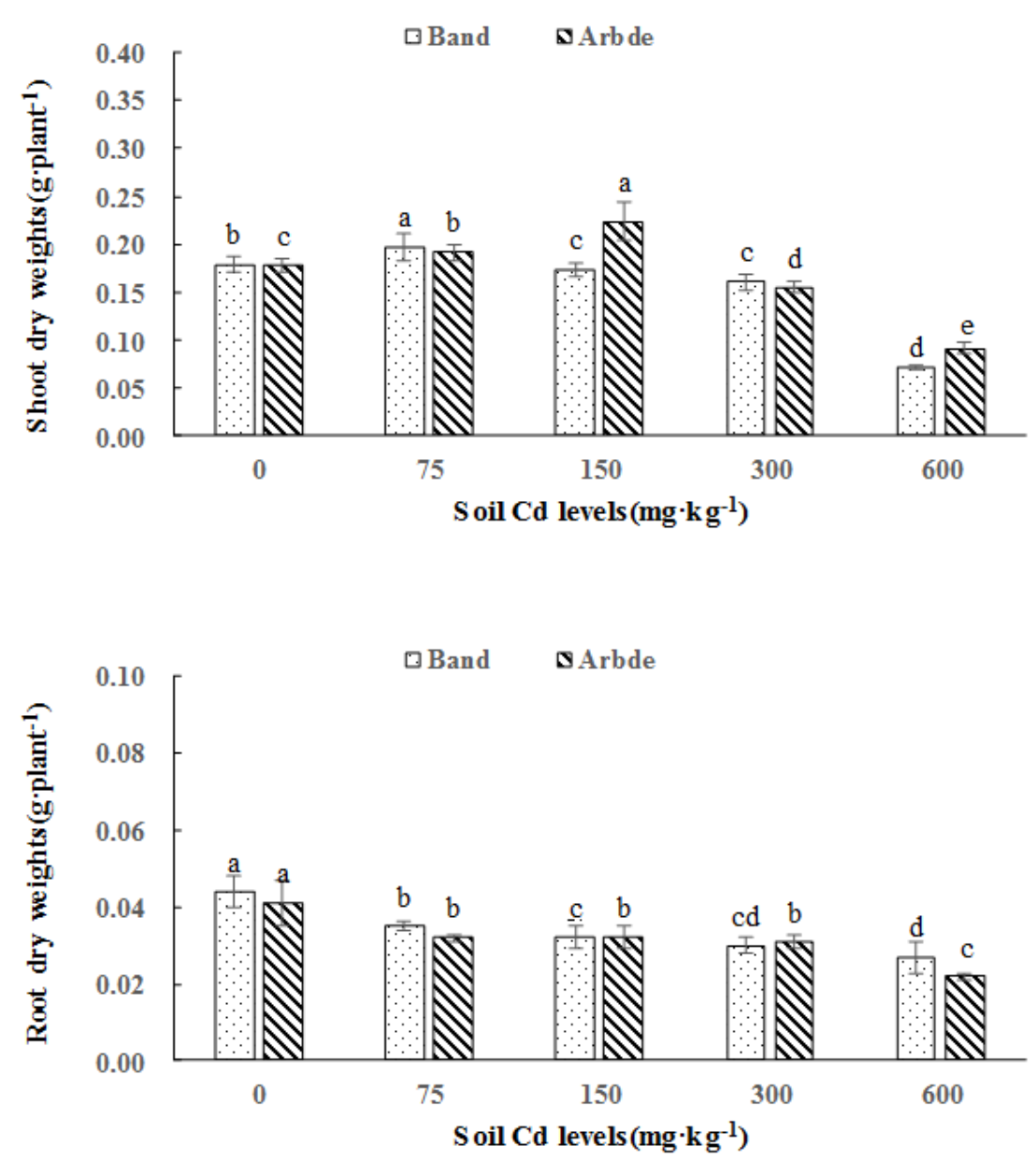

Figure 1. Effects of different Cd levels $\left(\mathrm{mg} \cdot \mathrm{kg}^{-1}\right)$ on dry weight of ryegrass; different letters $(a, b, c)$ indicate significant difference at $P \leq 0.05$ among different $C d$ levels in the same variety 


\section{Antioxidant enzyme activity}

Significant difference of the activities of SOD, POD and CAT in shoots and roots of ryegrass were found between different varieties and among different $\mathrm{Cd}$ pollution levels $(P<0.05)$ (Figs. 2-4). As shown in Figure 2, the activity of SOD in shoots of Band significantly increased with the increase of Cd level in soil, with increases of $14.52 \%$ $68.38 \%$ compared with the control, while the activity of SOD in shoots of Arbde decreased with the increase of Cd level in soil, with the decrease of $4.17 \%-41.67 \%$ compared with the control. The activity of SOD in roots of the two varieties increased with the increase of $\mathrm{Cd}$ level in soils, and highest activities of SOD in roots of Band and Arbde were observed at the Cd level of $75 \mathrm{mg} \cdot \mathrm{kg}^{-1}$ and respectively increased by $3.24 \%$ and $10.66 \%$ compared with the control.
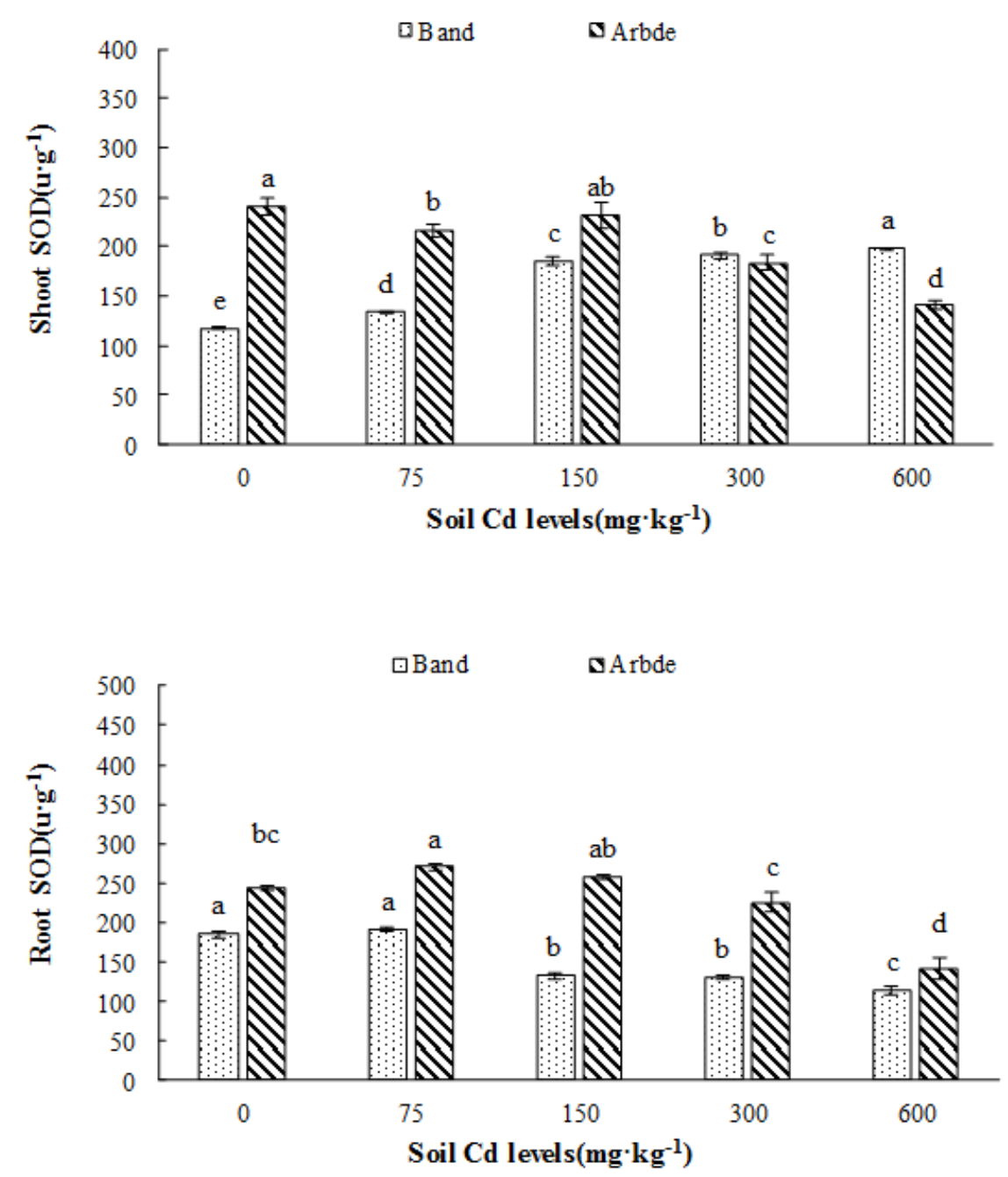

Figure 2. Effects of different cadmium levels on SOD activity in ryegrass; different letters $(a, b, c)$ indicate significant difference at $P \leq 0.05$ among different $C d$ levels in the same variety

As shown in Figure 3, the activity of CAT in shoots and roots of Band and Arbde increased significantly with the increase of Cd level in soils. Highest activities of CAT 
in shoots and roots were found in $150 \mathrm{mg} \cdot \mathrm{kg}^{-1} \mathrm{Cd}$, and respectively increased by $8.83 \%$ and $136.36 \%$ compared with the control. Under the same Cd level, the activity of CAT in roots of the two varieties ryegrass was lower than that in shoots.
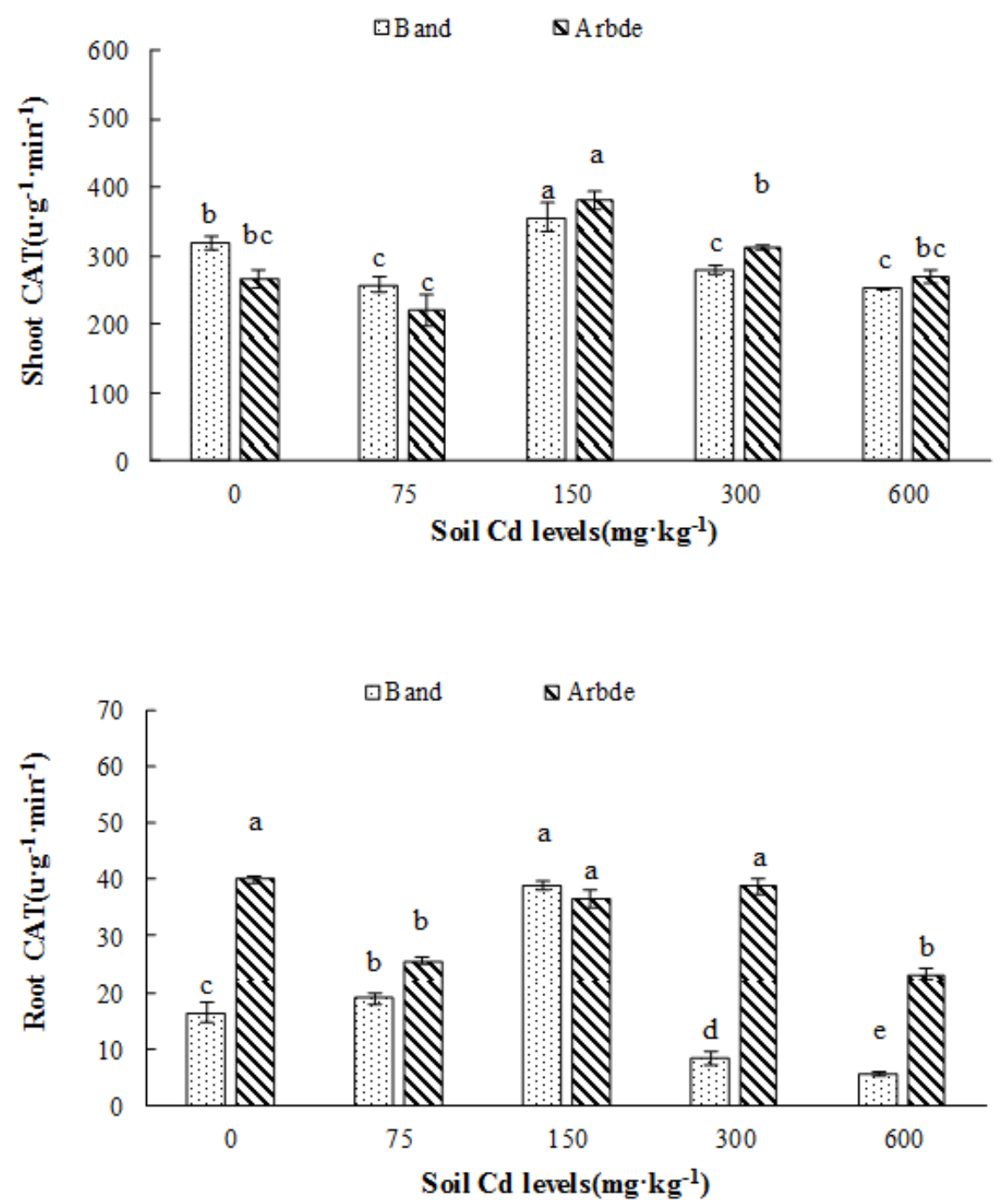

Figure 3. Effects of different cadmium levels on CAT activity in ryegrass; different letters $(a, b, c)$ indicate significant difference at $P \leq 0.05$ among different $C d$ levels in the same variety

As shown in Figure 4, the activity of POD in shoots and roots of the two varieties of ryegrass increased significantly with the increase of $\mathrm{Cd}$ level. The activity of POD in shoots and roots of Band respectively increased by $23.50 \%-201.67 \%$ and $7.42 \%$ $20.01 \%$ compared with the control, respectively. The activity of POD in shoots and roots of Arbde respectively increased by 50.62\%-232.06\% and $4.58 \%-59.62 \%$ compared with the control. 

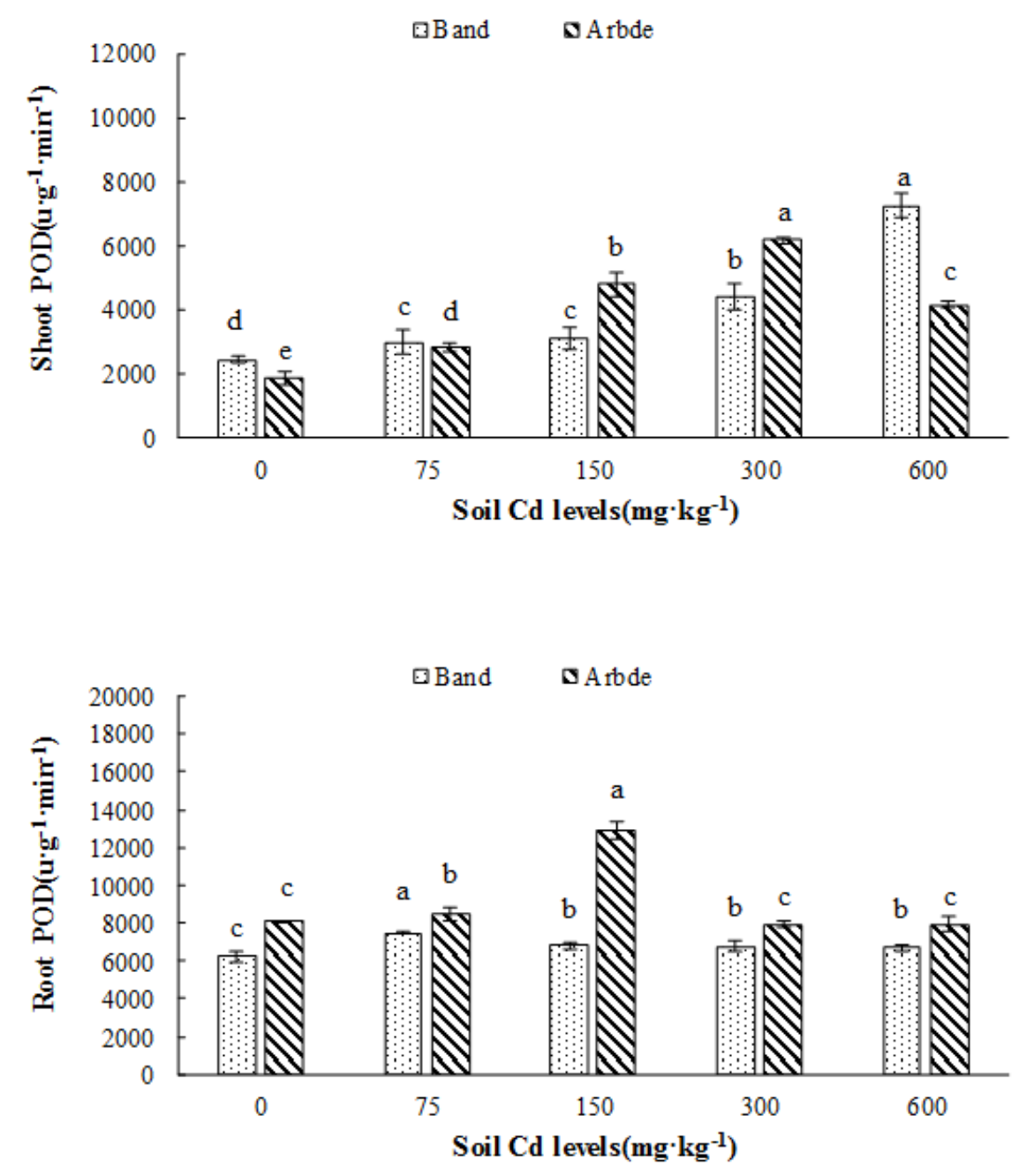

Figure 4. Effect of different cadmium levels on $P O D$ activity in ryegrass; different letters $(a, b, c)$ indicate significant difference at $P \leq 0.05$ among different $C d$ levels in the same variety

\section{MDA content}

As shown in Figure 5, the MDA content in shoots and roots of the two varieties of ryegrass increased significantly with the increase of Cd level. Highest MDA contents in shoots and roots of Band significantly increased by $2.78 \%$ and $88.05 \%$ at $150 \mathrm{mg} \cdot \mathrm{kg}^{-1}$ and $75 \mathrm{mg} \cdot \mathrm{kg}^{-1} \mathrm{Cd}$ respectively compared with the control. In the case of shoots and roots of Arbde, highest MDA contents in shoots and roots of Arbde significantly increased by $66.62 \%$ and $23.86 \%$ at $300 \mathrm{mg} \cdot \mathrm{kg}^{-1}$ and $150 \mathrm{mg} \cdot \mathrm{kg}^{-1} \mathrm{Cd}$ respectively compared with the control. 

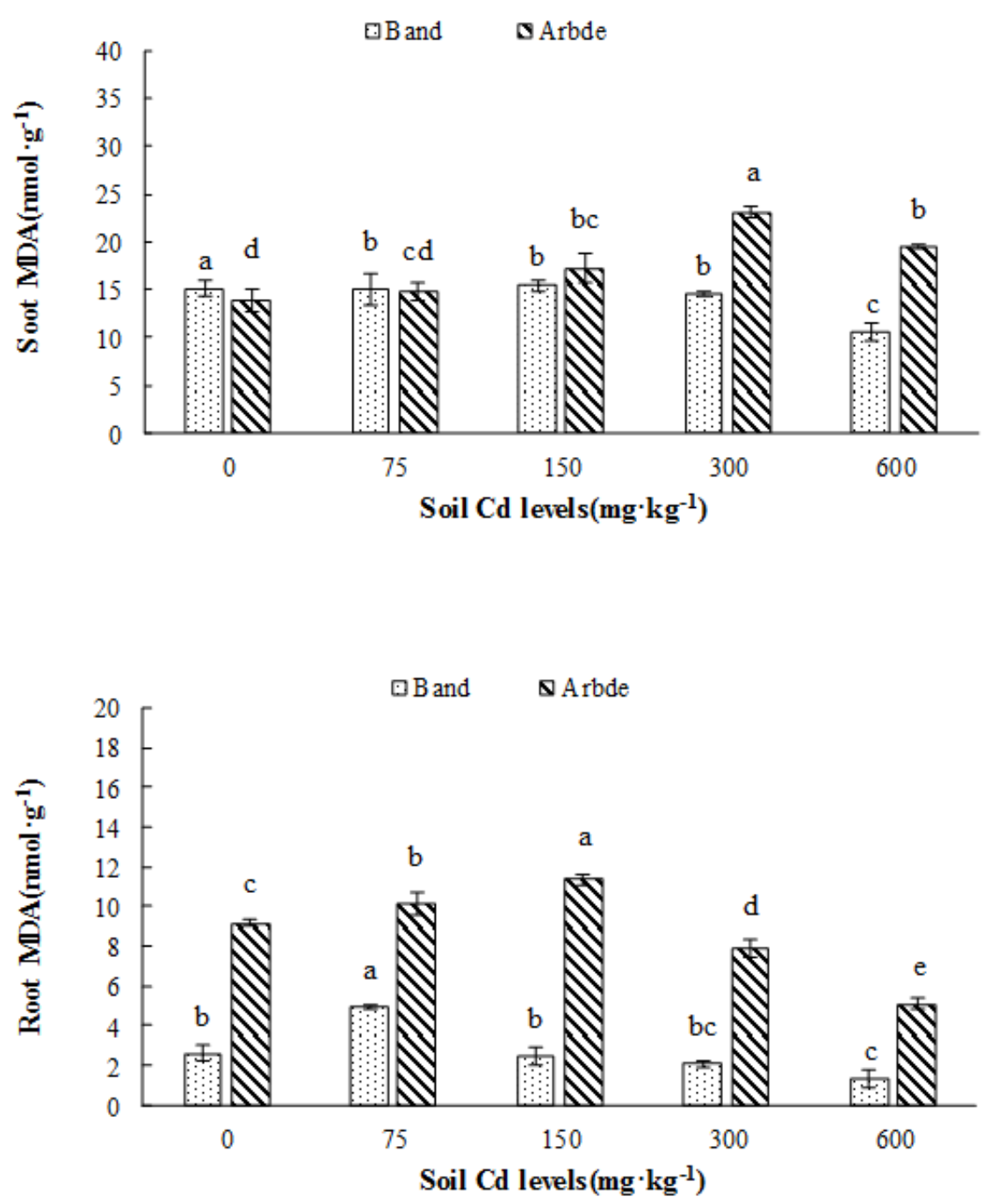

Figure 5. Effects of different cadmium levels on MDA content in ryegrass; different letters $(a, b, c)$ indicate significant difference at $P \leq 0.05$ among different $C d$ levels in the same variety

\section{Concentration of $C d$ in shoot and root}

As shown in Figure 6, Cd concentrations in shoots and roots of the two ryegrass varieties increased significantly with the increase of $\mathrm{Cd}$ level $(P<0.05)$. When exposed to $150 \mathrm{mg} \cdot \mathrm{kg}^{-1} \mathrm{Cd}, \mathrm{Cd}$ concentrations in shoots and roots of Band and Arbde were respectively as $171.827 \mathrm{mg} \cdot \mathrm{kg}^{-1}, 374.494 \mathrm{mg} \cdot \mathrm{kg}^{-1}$ and $169.122 \mathrm{mg} \cdot \mathrm{kg}^{-1}, 229.676$ $\mathrm{mg} \cdot \mathrm{kg}^{-1}$, which exceeded the critical value of cadmium hyperaccumulator $\left(100 \mathrm{mg} \cdot \mathrm{kg}^{-1}\right.$ $\mathrm{Cd})$. At the same cadmium level, $\mathrm{Cd}$ concentrations in roots of the two ryegrass varieties were higher than those in shoots, and $\mathrm{Cd}$ concentrations in shoots and roots of Band was lower than that of Arbde. 

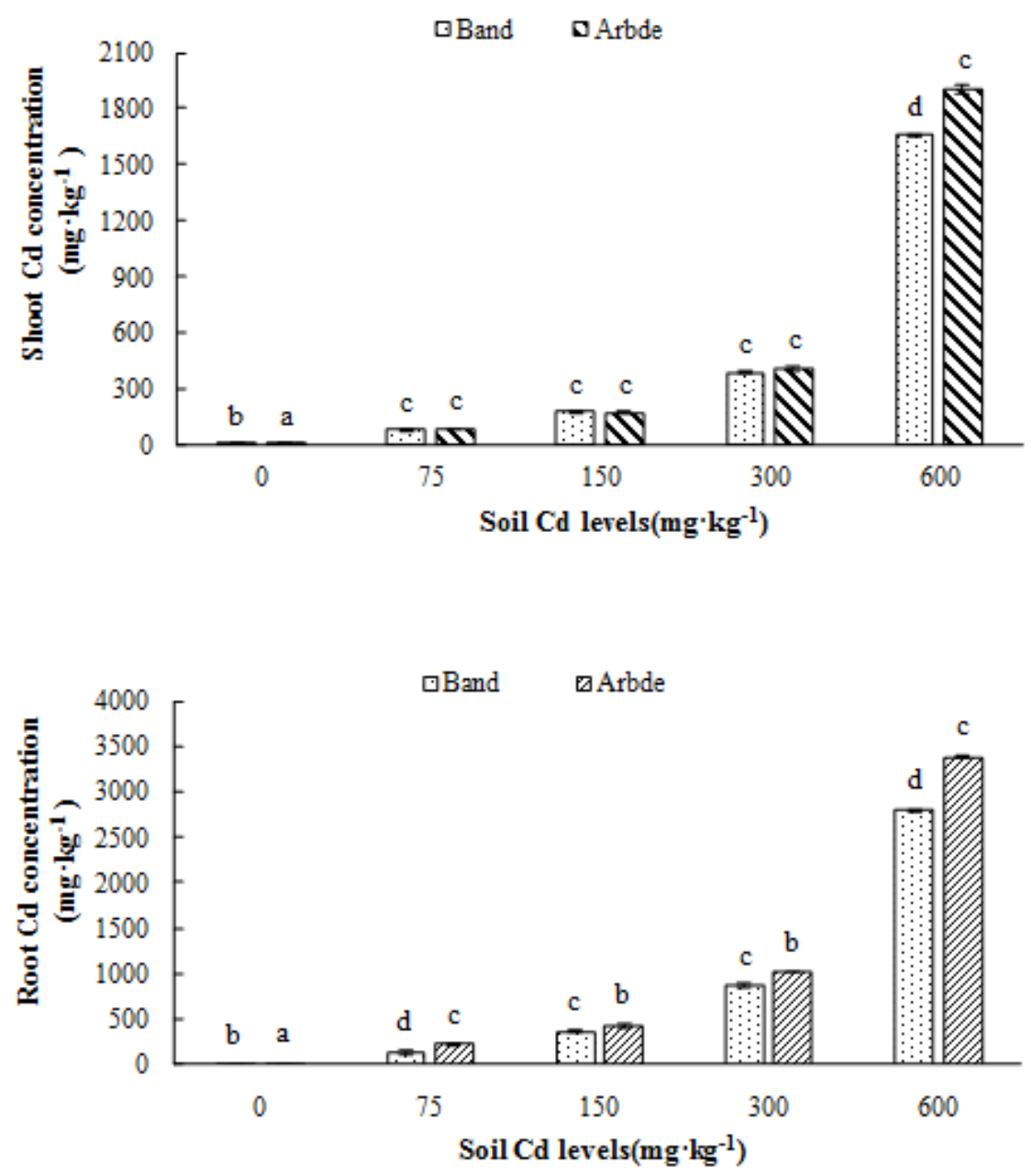

Figure 6. Effect of different $C d$ levels on $C d$ content in different parts of ryegrass; different letters $(a, b, c)$ indicate significant difference at $P \leq 0.05$ among different $C d$ levels in the same variety

\section{Cd accumulation in shoot and root}

As shown in Figure 7, Cd accumulation in shoots and roots of the two ryegrass varieties increased with the increase of level of cadmium in soils, and significant differences were found between varieties and among $\mathrm{Cd}$ treatments $(P<0.05)$. When exposed to $75-600 \mathrm{mg} \cdot \mathrm{kg}^{-1} \mathrm{Cd}, \mathrm{Cd}$ accumulations in shoots and roots of Band were 53.84-422.93 times and 8.10-116.56 times that of the control. Highest Cd accumulation in shoots was observed at $600 \mathrm{mg} \cdot \mathrm{kg}^{-1} \mathrm{Cd}$ by $118.977 \mathrm{ug} \cdot \mathrm{plants}^{-1}$; Cd accumulations in shoots and roots of Arbde were 25.72-304.23 times and 6.94-70.04 times that of the control. Under the same $\mathrm{Cd}$ level, the total amount of $\mathrm{Cd}$ accumulation in the plant (the sum of $\mathrm{Cd}$ accumulations in shoots and roots) of Arbde was greater than that of Band. 

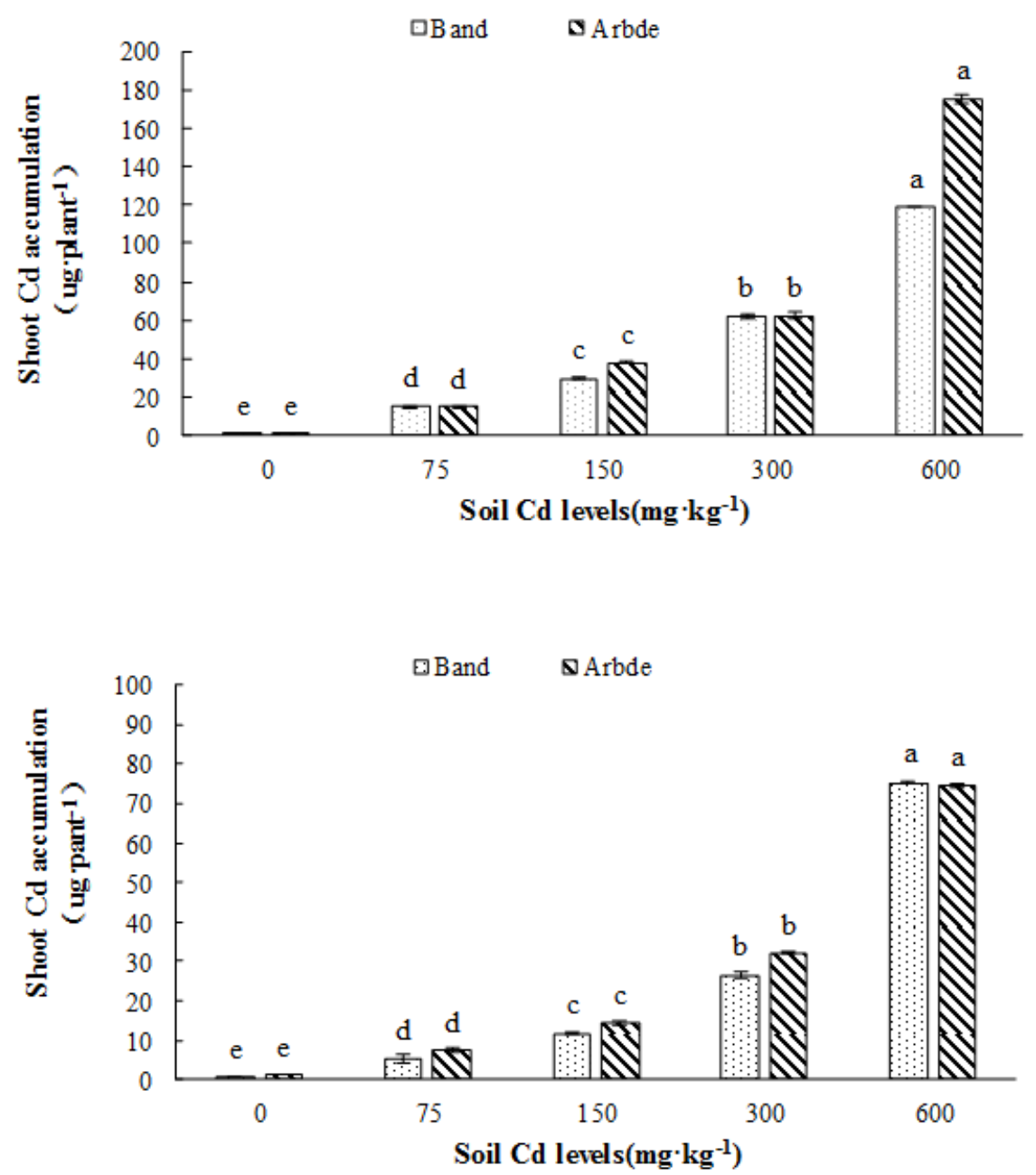

Figure 7. Effect of different cd levels on cd accumulation in different parts of ryegrass; different letters $(a, b, c)$ indicate significant difference at $P \leq 0.05$ among different $C d$ levels in the same variety

\section{Plant Cd fraction}

As shown in Figure 8, significant differences of distribution proportion of cadmium with different forms (FDC) in shoots of the two ryegrass were found between varieties and among $\mathrm{Cd}$ treatments $(P<0.05)$. The concentrations of $\mathrm{Cd}$ chemical forms in shoots of the two ryegrass varieties were in order of sodium chloride extraction state $\left(\mathrm{F}_{\mathrm{NaCl}}\right)>$ acetic acid extraction state $\left(\mathrm{F}_{\mathrm{HAc}}\right)>$ ionized water extraction state $\left(\mathrm{F}_{\mathrm{W}}\right)>$ residual state $\left(\mathrm{F}_{\mathrm{R}}\right)>$ hydrochloric acid extraction state $\left(\mathrm{F}_{\mathrm{HCl}}\right)>$ ethanol extraction state $\left(\mathrm{F}_{\mathrm{E}}\right) . \mathrm{F}_{\mathrm{NaCl}}, \mathrm{F}_{\mathrm{HAc}}$ and $\mathrm{F}_{\mathrm{W}}$ of Band and Arbde respectively accounted for $40.7 \%-52.8 \%$ and $38.2 \%-50.0 \%$, $19.2 \%-31.7 \%$ and $21.6 \%-36.3 \%, 12.5 \%-29.6 \%$ and $10.55 \%-27.17 \%$ of total amount of $\mathrm{Cd}$ extraction, while $\mathrm{F}_{\mathrm{E}}$ with higher activity had the lowest content, and only accounted for $1.1 \%-3.6 \%$ and $1.4 \%-4.0 \%$ of total amount of Cd extraction. 


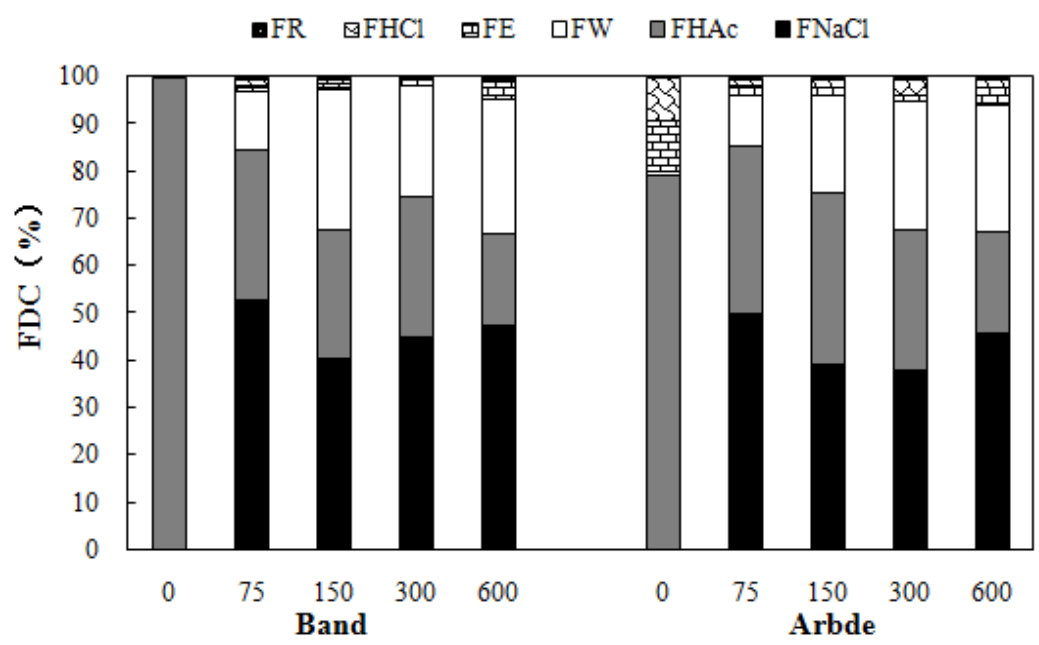

Figure 8. Effect of different Cd levels on the distribution of cadmium in ryegrass

\section{Soil Cd fraction}

The content and the distribution proportion (FDC) of Cd with different forms of the treated soils in the experiment were respectively shown in Figure 9 and Figure 10. The contents of $\mathrm{Cd}$ with different forms (EXC-Cd, CAB-Cd, FeMn-Cd, OM-Cd and RES$\mathrm{Cd})$ in soils increased with the increase of $\mathrm{Cd}$ level $(\mathrm{P}<0.05)$. The FDC of Cd with various chemical forms in soil was in order of EXC-Cd $>$ CAB-Cd $>$ FeMn-Cd $>$ RES$\mathrm{Cd}>\mathrm{OM}-\mathrm{Cd}$. The FDC of EXC-Cd in soil of Band and Arbde were respectively as $61.42 \%-82.64 \%$ and $55.09 \%-83.23 \%$. The FDC of OM-Cd was lowest with FDC of $0.87 \%-6.26 \%$. Under the same cadmium level, soil EXC-Cd concentration of Arbde were lower than that of Band, but no significant differences were found in other soil $\mathrm{Cd}$ chemical forms.

\section{Correlation between plant Cd concentration and soil Cd fraction}

As shown in Table 1, significant correlations were observed among Cd concentration of shoots in Band and EXC-Cd, CAB-Cd, FeMn-Cd and RES-Cd in soil, whose correlation coefficients were respectively as $0.966,0.943,0.803$ and 0.666 . Moreover, significant correlations were also found among $\mathrm{Cd}$ concentration in roots of Band and EXC-Cd, CAB-Cd, FeMn-Cd and RES-Cd in soil, whose correlation coefficients were respectively as $0.983,0.960,0.838$ and 0.687 . As shown in Table 2, significant correlations were observed among Cd concentration of shoots in Arbde and CAB-Cd in soil, whose correlation coefficient was 0.847 . Significant correlations were also found among $\mathrm{Cd}$ concentration in roots of Arbde and EXC-Cd and CAB-Cd in soil, whose correlation coefficients were respectively as 0.989 and 0.885 . 

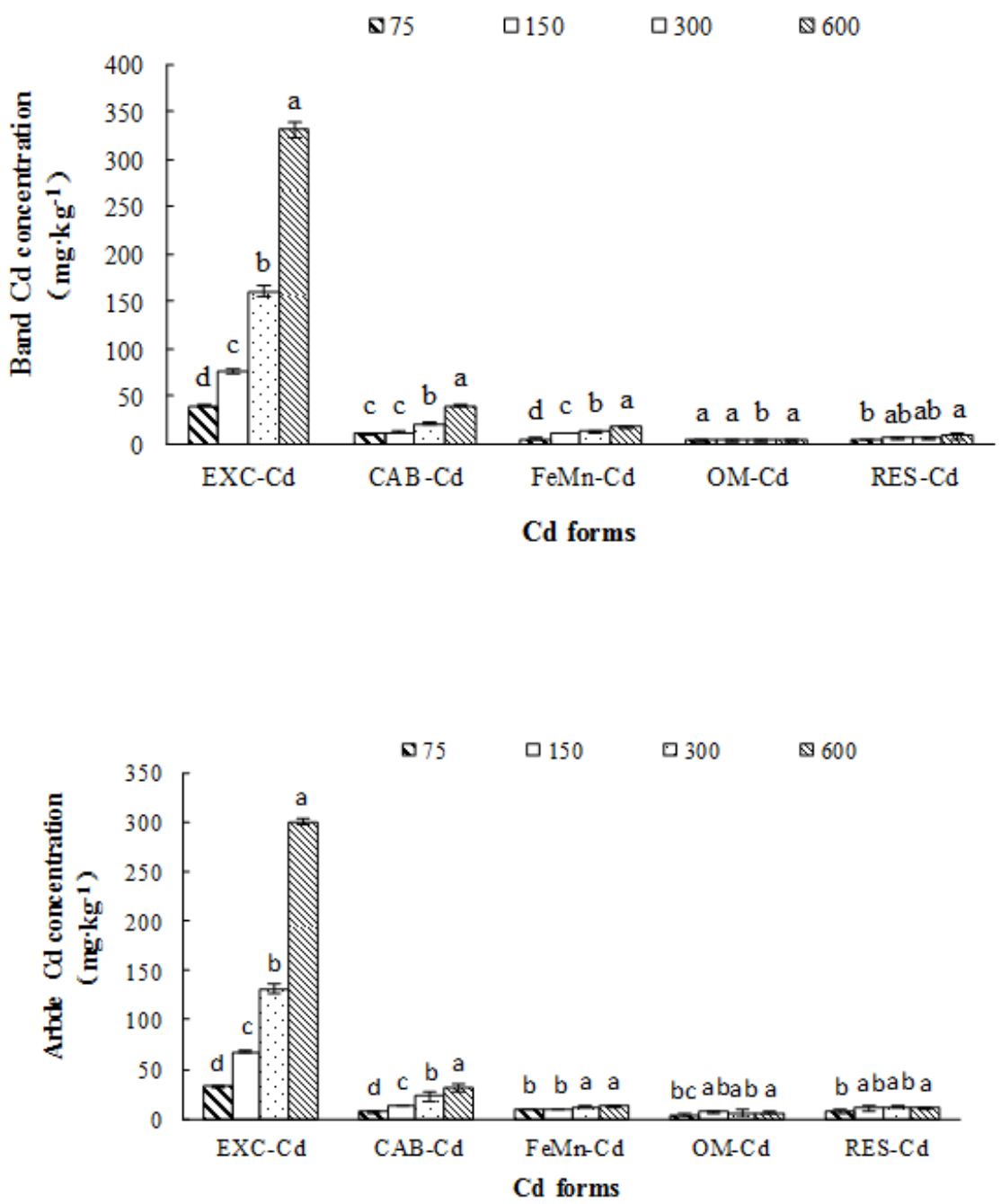

Figure 9. Effect of different $C d$ levels on concentration of $C d$ in soil; different letters $(a, b, c)$ indicate significant difference at $P \leq 0.05$ among different $C d$ levels in the same variety

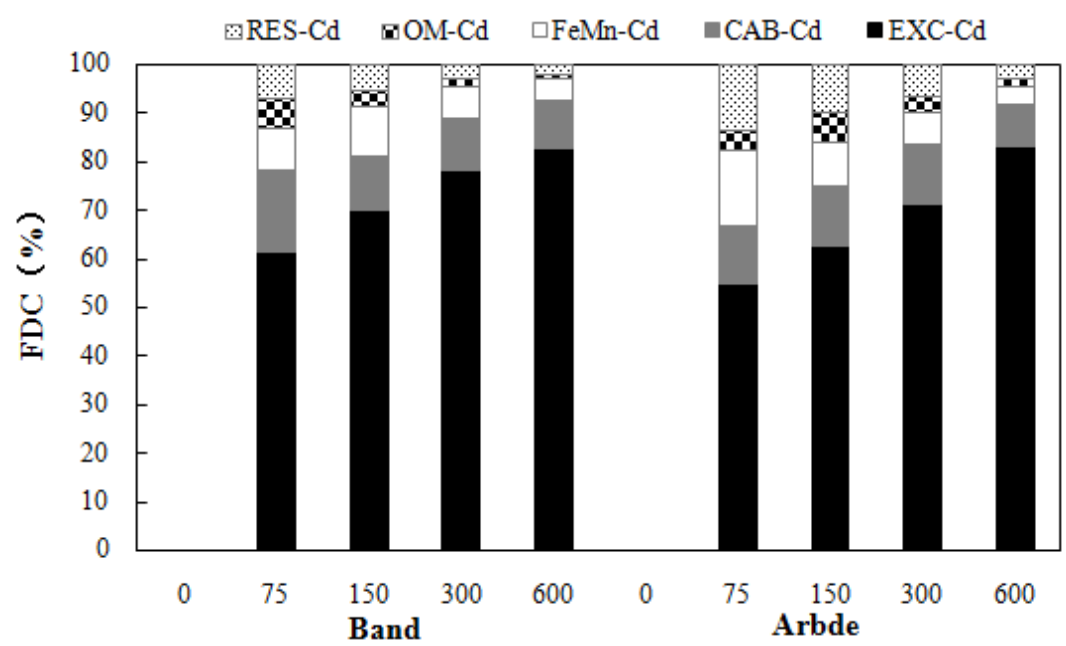

Figure 10. Effect of different Cd levels on Cd fraction distribution coefficient (FDC) in soils 
Table 1. Correlation coefficient between Cd contents of Band and the concentration of $C d$ fractions in soil

\begin{tabular}{c|c|c|c|c|c|c|c}
\hline & Shoot-Cd & Root-Cd & $\begin{array}{c}\text { EXC- } \\
\text { Cd }\end{array}$ & CAB-Cd & $\begin{array}{c}\text { FeMn- } \\
\text { Cd }\end{array}$ & OM-Cd & RES-Cd \\
\hline Shoot-Cd & 1 & & & & & & \\
Root-Cd & $0.996^{* *}$ & 1 & & & & & \\
EXC-Cd & $0.966^{*}$ & $0.983^{* *}$ & 1 & & & & \\
CAB-Cd & $0.943^{* *}$ & $0.960^{* *}$ & $0.988^{* *}$ & 1 & & & \\
FeMn-Cd & $0.803^{* *}$ & $0.838^{* *}$ & $0.911^{* *}$ & $0.930^{* *}$ & 1 & & \\
OM-Cd & 0.281 & 0.297 & 0.394 & $0.523^{*}$ & $0.615^{*}$ & 1 & \\
RES-Cd & $0.666^{* *}$ & $0.687 * *$ & $0.767 * *$ & $0.812^{* *}$ & $0.878^{* *}$ & $0.706^{* *}$ & 1 \\
\hline
\end{tabular}

Table 2. Correlation coefficient between Cd contents of Arbde and the concentration of Cd fractions in soil

\begin{tabular}{c|c|c|c|c|c|c|c}
\hline & Shoot-Cd & Root-Cd & $\begin{array}{c}\text { EXC- } \\
\text { Cd }\end{array}$ & CAB-Cd & $\begin{array}{c}\text { FeMn- } \\
\text { Cd }\end{array}$ & OM-Cd & RES-Cd \\
\hline Shoot-Cd & 1 & & & & & & \\
Root-Cd & $0.996^{* *}$ & 1 & & & & & \\
EXC-Cd & $0.973^{*}$ & $0.989^{* *}$ & 1 & & & & \\
CAB-Cd & $0.847^{* *}$ & $0.885^{* *}$ & $0.932^{* *}$ & 1 & & & \\
FeMn-Cd & $0.555^{*}$ & $0.609^{*}$ & $0.697^{* *}$ & $0.839^{* *}$ & 1 & & \\
OM-Cd & 0.405 & 0.449 & $0.546^{*}$ & $0.577^{*}$ & $0.698^{* *}$ & 1 & \\
RES-Cd & 0.396 & 0.459 & $0.567^{*}$ & $0.730^{* *}$ & $0.931^{* *}$ & $0.793^{* *}$ & 1 \\
\hline
\end{tabular}

\section{Discussion}

Under Cd stress, plants are often shown with the toxicity symptom of $\mathrm{Cd}$ such as growth inhibition and so on, and the toxic effects increase with the increase of Cd level (Antoniadis et al., 2017). However, some studies have pointed out that low Cd stimulates and promotes plant growth (Shi et al., 2015). In this experiment, shoot dry weights of Arbde and Band firstly increased with the increase of Cd level in soil, and then decreased. $75 \mathrm{mg} \cdot \mathrm{kg}^{-1} \mathrm{Cd}$ and $150 \mathrm{mg} \cdot \mathrm{kg}^{-1} \mathrm{Cd}$ stimulate the growth of Band and Arbde, which was probably because the perennial ryegrass was likely to distribute $\mathrm{Cd}^{2+}$ to non metabolic active site such as vacuole, apoplast and so on in order to reduce the toxicity of $\mathrm{Cd}^{2+}$ to cells (Liu et al., 2013).

When exposed to $\mathrm{Cd}$, large amount of reactive oxygen species and peroxides in plants are produced, such as $\mathrm{O}_{2}^{-}, \mathrm{OH}^{-}, \mathrm{H}_{2} \mathrm{O}_{2}$, etc., resulting in disruption of cell membrane integrity and stability, and peroxidation damage to the plant (Zhang et al., 2015). These free radicals and peroxides in plants are removed or reduced by increasing the activities of antioxidant enzymes of SOD, POD and CAT. SOD, as the first line of defense of plant antioxidants, can eliminate excess superoxide anion in cells, and POD and CAT can make $\mathrm{H}_{2} \mathrm{O}_{2}$ differentiate into non-toxic water and oxygen molecules so as to alleviate the peroxidation damage of $\mathrm{Cd}$ to the plant ( $\mathrm{Li}$ et al., 2013; Wang et al., 2008). Malondialdehyde (MDA) is the product of membrane lipid peroxidation in plant cells subjected to oxidative stress under stress, which is usually regarded as physiological indexes of oxidative damage, and its content can reflect the intensity of 
plant responses to stress conditions and the extent of cell membrane lipid peroxidation (Becana et al., 2000).

In the present study, the activities of SOD and POD enzymes in the two ryegrass varieties increased firstly with the increase of $\mathrm{Cd}$ in soil, and then decreased, which was in line with the typical defense characteristics of plants under Cd stress. This result was consistent with the result of Yang et al. (2000). The activity of CAT decreased with the increase of $\mathrm{Cd}$ level in soil. The reason may be that CAT is the most sensitive antioxidant enzyme to heavy metals, and its activity is firstly inhibited, causing the elimination of $\mathrm{H}_{2} \mathrm{O}_{2}$ in the body to be blocked and only to be conducted by POD, thus the activity of POD increased (Yu et al., 2010). The content of MDA increased firstly with the increase of $\mathrm{Cd}$ in soil, and then decreased, and can exhibit strong reactive oxygen tolerance, which was probably because the active oxygen in the body can be eliminated at high Cd stress (Xu et al., 2010).

Cadmium with strong mobility is easy to be absorbed by plants, and most plants can transfer Cd from roots to shoots (Zhang et al., 2013). In the present study, Cd concentrations in roots of the two ryegrass varieties were higher than those in shoots. It suggested that roots had stronger $\mathrm{Cd}$ enrichment ability, but the abilities to transfer $\mathrm{Cd}$ from root to shoot were weaker. This result is similar to the reports of Huang et al. (2016), Chen et al. (2014) and Sun et al. (2016). The Cd concentration in shoot of Cd hyperaccumulator with the critical content of $100 \mathrm{mg} \cdot \mathrm{kg}^{-1}$ was 100 times as much as common plants (Li et al., 2016). In this experiment, when exposed to high $\mathrm{Cd}(\geq 150$ $\left.\mathrm{mg} \cdot \mathrm{kg}^{-1}\right)$, Cd concentration in shoots of Band and Arbde both exceeded the critical value of hyperaccumulator, and the two ryegrass varieties with strong tolerance to $\mathrm{Cd}$ had no obvious toxic symptoms, which were similar to the findings of Sun et al. (2016). Under the same $\mathrm{Cd}$ level in soil, $\mathrm{Cd}$ concentration and $\mathrm{Cd}$ accumulation in shoots and roots of Arbde were higher than those of Band. It was suggested that Arbde was more effective in remediation of cadmium contamination in soils due to higher plant biomass and greater $\mathrm{Cd}$ accumulation.

There were obvious differences in $\mathrm{Cd}$ migration ability of different $\mathrm{Cd}$ chemical forms in plants, which further affects the transport and transfer of cadmium in plants and the toxicity of cadmium to plants ( $\mathrm{Li}$ et al., 2015). In the present study, $\mathrm{F}_{\mathrm{NaCl}}$ was dominant chemical form of cadmium in Band and Arbde due to $\mathrm{Cd}$ had a strong affinity to sulfhydryls in proteins or other organic compounds, which was consistent with the early report by Zhang et al. (2011). The $\mathrm{F}_{\mathrm{E}}$ with higher activity in Band and Arbde only accounted for $1.1 \%-3.6 \%$ and $1.4 \%-4.0 \%$ of the total amount of $\mathrm{Cd}$ extraction respectively, thus greatly limiting the toxic effect of $\mathrm{Cd}$ on ryegrass growth.

The available cadmium in soil is one of important factors affecting Cd uptake by plants (Castaldi et al., 2005). In the experiment, the concentration of various $\mathrm{Cd}$ chemical forms in soils were significantly positively correlated with $\mathrm{Cd}$ concentrations of shoot and root in the two ryegrass varieties $(P<0.01)$ (excepted for $\mathrm{OM}-\mathrm{Cd})$, which were consistent with the study of Yang et al. (2011). EXC-Cd was dominant chemical form of cadmium in soils of the two ryegrass, and the FDC of $\mathrm{Cd}$ with various chemical forms in soil was in order of EXC-Cd > CAB-Cd> FeMn-Cd > RES-Cd > OM-Cd, which was consistent with the results of Chen (2016). With the increase of Cd level, the percentage of EXC-Cd accounting for the total cadmium was also increasing, which was consistent with the research results reported by Zhang et al. (2013). Cadmium concentrations of roots in the two ryegrass varieties had a very significant positive correlation with EXC-Cd, indicating the absorption of $\mathrm{Cd}$ concentration in roots of 
ryegrass and the exchangeable cadmium content in soil, which was consistent with the results of (Yang et al., 2011). Under the same Cd level, the concentrations of EXC-Cd in soil of Band was higher than that of Arbde, corresponding to the result that $\mathrm{Cd}$ concentrations in shoots and roots of Arbde were higher than those of Band (excepted for shoot $\mathrm{Cd}$ concentration at $150 \mathrm{mg} \cdot \mathrm{kg}^{-1} \mathrm{Cd}$ ), which was probably caused by the difference between varieties, while the specific reasons need to be studied.

\section{Conclusion}

The shoot dry weight of the two ryegrass varieties (Band and Arbde) increased firstly and then decreased with the increase of $\mathrm{Cd}$ level in soil, and reached the maximum at 75 $\mathrm{mg} \cdot \mathrm{kg}^{-1}$ and $150 \mathrm{mg} \cdot \mathrm{kg}^{-1}$ of $\mathrm{Cd}$ respectively. The activities of SOD, POD and the contents of MDA in shoots and roots of the two ryegrass varieties increased with the increase of $\mathrm{Cd}$ level in soil, while CAT activity decreased. The concentrations of $\mathrm{Cd}$ chemical forms in shoots of the two ryegrass varieties were in order of $\mathrm{F}_{\mathrm{NaCl}}>\mathrm{F}_{\mathrm{HAC}}>$ $\mathrm{F}_{\mathrm{W}}>\mathrm{F}_{\mathrm{R}}>\mathrm{F}_{\mathrm{HCl}}>\mathrm{F}_{\mathrm{E}}$. The order of $\mathrm{FDC}$ of $\mathrm{Cd}$ in each form was described as EXC-Cd $>$ $\mathrm{CAB}-\mathrm{Cd}>$, FeMn-Cd>, RES-Cd > OM-Cd. Except for OM-Cd. the concentration of various $\mathrm{Cd}$ chemical forms in soils were significantly positively correlated with $\mathrm{Cd}$ concentrations of shoot and root in the two ryegrass varieties $(P<0.01)$ (excepted for OM-Cd). Compared with the two ryegrass varieties, Arbde was more effective in remediation of cadmium contamination in soils due to stronger tolerance to $\mathrm{Cd}$, higher biomass and greater $\mathrm{Cd}$ accumulation. Recommendations for future studies are to found the plants or varieties with high Cd-accumulation are needed to be screened out and cultured, and their genes are induced into plants with great biomass, rapid growing and strong adaptability, so that ideal $\mathrm{Cd}$ super-accumulation plants.

Acknowledgments. This work was supported by Fund of China Agriculture Research System (CARS-23), the National Science and Technology Pillar Program of China (No. 2007BAD87B10), Chinese Undergraduate Training Programs for Innovation and Entrepreneurship (201610635028), and Southwestern University Undergraduate Science and Technology Innovation "Guangjiong" Training Project (20150490).

\section{REFERENCES}

[1] Ahamed, A. J., Loganathan, K. (2017): Water quality concern in the Amaravathi River Basin of Karur district: a view at heavy metal concentration and their interrelationships using geostatistical and multivariate analysis. - Geology, Ecology, and Landscapes 1(1): 19-36.

[2] Antoniadis, V., Shaheen, S. M., Boersch, J., Froohne, T., Du, L. G., Rinklebe, J. (2017): Bioavailability and risk assessment of potentially toxic elements in garden edible vegetables and soils around a highly contaminated former mining area in Germany. - J. Environ. Manage 186: 192-200.

[3] Becana, M. D., Dalton, D. A., Moran, J. F. (2000): Reactive oxygen species and antioxidants in legume nodules. - Physiol. Plantarum 109(4): 372-381.

[4] Castaldi, P., Santona, L., Melis, P. (2005): Heavy metal immobilization by chemical amendments in a polluted soil and influence on white lupin growth. - Chemosphere 60(3): 365-371.

[5] Chen, R. (2016): Mechanism and Remediation Effect of Biochar and Soil Conditioner on Cadmium Contaminated Soil. - Chongqing: Southwest University. 
[6] Chen, Y. H., Liu, X. Y., Wang, M., Wang, X. J., Yan, X. M. (2014): Cadmium tolerance, accumulation and relationship with Cd subcellular distribution in Ricinus communis L. Environ. - Sci-China 34(9): 2440-2446.

[7] Chen, Y. Q., Jiang, L., Xu, W. H., Chi, S. L., Chen, X. G., Xie, W. W., Xiong, S. J., Zhang, J. Z., Xiong, Z. T. (2015): Effect of ryegrass and arbuscular mycorrhizal on Cd absorption by varieties of tomatoes and cadmium forms in soil. - Environ. Sci. 36(12): 4642-4650.

[8] Du, P., Xue, N., Liu, L., Li, F. (2008): Distribution of $\mathrm{Cd}, \mathrm{Pb}, \mathrm{Zn}$ and $\mathrm{Cu}$ and their chemical speciations in soils from a peri-smelter area in northeast China. - Environ. Geol. 55(1):205-213.

[9] Feng, P., Sun, L., Shen, X. H., Jiang, C., Li, R. L., Zeng, Z. J., Zheng, H. Y., Zhang, H., Guo, W., Han, X. D., Hong, Y. N. (2016): Response and enrichment ability of perennial ryegrass under lead and cadmium stresses. - Acta Pratacult. Sin. 25(1):153-162.

[10] Grant, C. A., Clarke, J. M., Duguid, S., Chaney, R. L. (2008): Selection and breeding of plant cultivars to minimize cadmium accumulation. - Sci. Total Environ. 390(2-3): 301310 .

[11] Hashemi, N. (2017): Recognizing the potential of sustainable use of pasture resources in south khorasan province with approch of carrying capacity. Environment Ecosystem Science, 1(2): 09-12.

[12] Hejazi, S.M., Lotfi, F., Fashandi, H., Alirezazadeh, A. (2017): Serishm: an eco-friendly and biodegradable flame retardant for fabrics. Environment Ecosystem Science, 1(2): 0508 .

[13] Huang, D. F., Xi, J. B., Zhao, Y. L., (2016): The Physiological Response of Two Varieties of Lolium perenne Under Cadmium Stress. - Nor. Horticul. (3): 66-68.

[14] Issaka, S., Ashraf, M. A. (2017): Impact of soil erosion and degradation on water quality: a review. - Geology, Ecology, and Landscapes 1(1): 01-11.

[15] Li, H. T., Dong, R. (2015): Pb \& Cd absorption and accumulation characteristics, subcellular distribution and chemical forms in two types of Hemerocallis plants. - J. South Chin. Agric. Univ. 36(4): 59-64.

[16] Li, P., Peng, X. J., Luan, Z. K., Zhao, T. K., Zhang, C. J., Liu, B. C. (2016): Effects of red mud addition on cadmium accumulation in cole (Brassica campestris L.) under high fertilization conditions. - J. Soil Sediment 16(8): 2097-2104.

[17] Li, X., Yue, H., Wang, S., Huang, L. Q., Ma, J., Guo, L. P. (2013): Research of different effects on activity of plant antioxidant enzymes. - China Journal of Chinese Materia Medica 38(7): 973-978.

[18] Liu, J. X., Xu, X. Q., Qian, Y. Q., Ju, G. S., Han, L., Sun, Z. Y. (2013): Responses of antioxidative enzymes and phytochelatins in Lolium perenne to $\mathrm{Cd} 2+$ stress. - Chin. J. Ecol. 32(7):1787-1793.

[19] Liu, Y. Z., Xiao, T. F., Ning, Z. P., Jia, Y. L., Li, H. J., Yang, F., Jiang, T., Sun, M., (2013): Cadmium and selected heavy metals in soils of Jianping area in Wushan country, the three gorges region: distribution and source recognition. - Environ. Sci. 34(6):2390-2398.

[20] Liu. Y., Xiao, T., Baveye, P. C., Zhu, J., Ning, Z., Li, H. (2015): Potential health risk in areas with high naturally-occurring cadmium background in southwestern China. Ecotox. Environ. Safe. 112: 122-131.

[21] Radan, A., Latifi, M., Moshtaghie, M., Ahmadi, M., Omidi, M. (2017): Determining the Sensitive Conservative Site in Kolah Ghazi National Park, Iran, In Order to Management Wildlife by Using GIS Software. Environment Ecosystem Science, 1(2): 13-15.

[22] Reiser, R., Simmler, M., Portmann, D., Cucas, L., Schulin, R., Robinson, B. (2014): Cadmium concentrations in New Zealand pastures: relationships to soil and climate variables. - J. Environ. Qual. 43(3): 917.

[23] Shi, C., Wang, C. L., Huang, C. F., An, S. Z. (2015): Effects of Cd stress on the growth and physiological charactteristics of Avena fatua seedlings. - Acta Agrect. Sin. 23(3): 526-532.

[24] Sun, Y. Y., Guan, P., He, B., Shi, J. M. (2016): Effects of Cd stress on Cd accumulation, 
physiological response and ultrastructure of Lolium multiflorum. - Pratacult. Sci. 33(8):1589-1597.

[25] Tessier, A., Campbell, P. G. C., Bisson, M. (1979): Sequential extraction procedure for the speciation of particulate trace metals. - Anal. Chem. 51(7): 844-851.

[26] Vazdani, S., Sabzghabaei, G., Dashti, S., Cheraghi, M., Alizadeh, R., Hemmati, A. (2017): Fmea Techniques Used in Environmental Risk Assessment. Environment Ecosystem Science, 1(2): 16-18.

[27] Wang, H., Zhao, S. C., Xia, W. J., Wang, X. B., Fan, H. L., Zhou, W. (2008): Effect of cadmium stress on photosynthesis, lipid peroxidation and antioxidant enzyme activities in maize (Zea mays L.) seedlings. - Plant Nutrition and Fertilizing Science 14(1): 36-42.

[28] Wu, Q. L., Wang, W. C., He, S. Y. (2014): Enhancement of GA3 and EDTA on Lolium perenne to remediate $\mathrm{Pb}$ contaminated soil and its detoxification mechanism. - Chin. J. Appl. Ecol. 25(10): 2999-3005.

[29] Xiang, T. (2014): Study on remedial of Cd-Contaminated soil by herbaceous flowers. Chongqing: Chongqing University.

[30] Xiao, H., Wang, M., Sheng, S. (2017): Spatial evolution of URNCL and response of ecological security: a case study on Foshan City. Geology, Ecology, and Landscapes, 1(3): 190-196.

[31] Xu, W. H., Wang, H. X., Liu, H., Balwant, S. (2007): Effects of individual and combined pollution of $\mathrm{Cd}$ and $\mathrm{Zn}$ on root exudates and rhizosphere $\mathrm{Zn}$ and $\mathrm{Cd}$ fractions in ryegrass (Loliurn perenne L.). - Environ. Sci. 28(9): 2089-2095.

[32] Xu, W., Kachenko, A. G., Singh, B. (2010): Effect of soil properties on arsenic hyperaccumulation in pteris vittata and pityrogramma calomelanos var. austroamericana. - Int. J. Phytoremediat 12(12): 174-187.

[33] Yang, J. H., Wang, C. L., Dai, H. L. (2008): Soil agrochemical analysis and environmental monitoring. - China Land Press, Beijing.

[34] Yang, S., Li, J., Song, Y. (2017): Application of surfactant Tween 80 to enhance Fenton oxidation of polycyclic aromatic hydrocarbons (PAHs) in soil pre-treated with Fenton reagents. Geology, Ecology, and Landscapes, 1(3): 197-204.

[35] Yang, W. D., Chen, Y. T. (2008): Membrane leakage and antioxidant enzyme activities in roots and leaves of salix matsudana with cadmium stress. - Acta Botanica Boreali Occidentalia Sinica 28(11): 2623-2269.

[36] Yang, Y., Nan, Z., Zhao, Z., Wang, Z., Wang, S., Wang, X., Jin, W., Zhao, C. (2011): Bioaccumulation and translocation of cadmium in cole (Brassica campestris L.) and celery (Apium graveolens) grown in the polluted oasis soil, Northwest of China. - J. Environ. Sci-China 23(8): 1368-1374.

[37] Yu, K. L., Meng, Q. M., Zou, J. H. (2010): Effects of $\mathrm{Cd}^{2+}$ on seedling growth, chlorophyll contents and ultrastructures in maize. - Acta Agric. Boreali Sin. 25(3): 118123.

[38] Zhang, X. J., Liu, J. Z., Xu, W. H., Chen, G. Q., Wang, H. X., Zhang, H. B., Han, G. Q., Zeng, H. J., Lan, C. T., Xiong, Z. T., Wei, Q. S. (2011): Effect of phosphor on accumulation and chemical forms of cadmium, and physiological characterization in different varieties of capsicum annuum L. - Environ. Sci. 32(4): 1171-1176.

[39] Zhang, X., Li, K. W., Chen, K. J., Liang, J., Cui, L. J. (2013): Effects of cadmium stress on seedlings growth and active ingredients in salvia miltiorrhiza. - Plant Sci. J. 31(6): 583-589.

[40] Zhang, Y. P., Shen, R. G., Yao, X. Q., Chen, Y. Y. (2015): Effects of cadmium stress on antioxidant enzyme activities and photosynthesis in melon seedlings. - Chin. Agric. Bull. 31(34): 82-88.

[41] Zhao, S., Chen, T. (2017): Design and development of national geographic condition monitoring system based on WebGIS. - Geology, Ecology, and Landscapes 1(1): 12-18. 